\title{
Significance of Feedback Inhibition of Insulin Secretion by Insulin in Healthy Non-obese Men
}

\author{
Hideyoshi KAGA*1), Yoshifumi TAMURA*1) 2), SAORI KAKEHI*2), YUKI SOMEYA*2), \\ RURIKO SUZUKI*1), KAGEUMI TAKENO*1), TAKASHI FUNAYAMA*1), \\ YASUHIKO FURUKAWA*1), HIROTAKA WATADA*1) 2) \\ *1) Department of Metabolism \& Endocrinology, Juntendo University Graduate School of Medicine, Tokyo, Japan, \\ *2) Sportology Center, Juntendo University Graduate school of Medicine, Tokyo, Japan
}

Endogenous insulin secretion is suppressed during hyperinsulinemic euglycemic clamp, which is known as a feedback inhibition of insulin secretion (FI-IS) by insulin. Since FI-IS is impaired in obese subjects, inadequate FI-IS may partly contribute to enhanced insulin secretion seen in obesity with insulin resistance. However, significance of FI-IS in non-obese healthy subjects is unknown. To clarify the significance, we studied 49 non-obese healthy Japanese men. We evaluated steady state serum C-peptide (SSSC) and muscle insulin sensitivity (MIS) by hyperinsulinemic euglycemic clamp with tracer (insulin infusion rate $=20 \mathrm{mU} / \mathrm{m}^{2}$ per $\mathrm{min}$ ). We also measured intrahepatic lipid (IHL) by ${ }^{1} \mathrm{H}-\mathrm{MRS}$. Based on the median of SSSC, we divided the subjects into low FI-IS group and high FI-IS group and compared clinical parameters. While fasting C-peptide level was comparable between the groups, the SSSC was suppressed by $50 \%$ from baseline in the high FI-IS group (1.14 \pm 0.39 to $0.57 \pm 0.24 \mathrm{ng} / \mathrm{ml}, \mathrm{p}<0.001)$, but less suppressed in the low FI-IS group (1.34 \pm 0.34 to $1.19 \pm 0.24$ $\mathrm{ng} / \mathrm{ml}, \mathrm{p}=0.054)$. Although most of metabolic parameters such as fasting glucose, lipid levels and visceral fat volume were comparable between the groups, low FI-IS group showed IHL accumulation ( $3.0 \pm 4.2$ vs. $0.6 \pm$ $0.2 \%, \mathrm{p}=0.04)$ and impaired MIS $\left(0.19 \pm 0.04\right.$ vs. $\left.0.28 \pm 0.08 \mathrm{mg} / \mathrm{kg} \mathrm{FFM} \cdot \mathrm{min}^{-1} \cdot \mu \mathrm{U}^{-1} \cdot \mathrm{m} l, \mathrm{p}<0.001\right)$, compared with high FI-IS group. Consistently, we observed elevated AUC of insulin during $75 \mathrm{~g}-\mathrm{OGTT}$ in low FI-IS group $\left(6.6 \pm 3.0\right.$ vs. $\left.3.9 \pm 2.0 \mu \mathrm{U} \cdot \mathrm{min} / \mathrm{ml} \cdot 10^{3}, \mathrm{p}=0.001\right)$, while AUC of glucose was comparable. In conclusion, even in healthy non-obese men, subjects with inadequate FI-IS were existed and those were characterized by impaired MIS and hyperinsulinemia during OGTT. These data suggested that impaired FI-IS may be early change to maintain metabolic status through enhancing insulin secretion in the face of moderate muscle insulin resistance in healthy non-obese men.

Key words: feedback inhibition of insulin secretion, insulin resistance, hyperinsulinemia

Corresponding author: Hideyoshi Kaga

Department of Metabolism \& Endocrinology, Juntendo University Faculty of Medicine

2-1-1 Hongo, Bunkyo-ku, Tokyo 113-8421, Japan

TEL: +81-3-3813-3111 E-mail: hkaga@juntendo.ac.jp

〔Received Nov. 29, 2017〕〔Accepted Feb. 13, 2018〕

Copyright (C) 2018 The Juntendo Medical Society. This is an open access article distributed under the terms of Creative Commons Attribution License (CC BY), which permits unrestricted use, distribution, and reproduction in any medium, provided the original source is properly credited. doi: $10.14789 /$ jmj .2018.64.JMJ18-P414 